\title{
Development of the SWOT Method with the addition of elements of Aspirations and Results in the Music Industry
}

\author{
Kanggep Andrijana Kusuma \\ Music Study Program, Faculty of Arts and Literature \\ Jl. Setiabudhi 193, Bandung, 40154, Indonesia \\ kanggepandriana@gmail.com
}

\begin{abstract}
The development of strategies to win business competition is growing and is becoming one of the most important and a mainstay of every company in planning strategies for achieving organizational goals both now and in the future. The object under study is a swot analysis with added elements of aspiration and result with the aim of providing better results. From that thought, the well-known SWOT methodology was combined with several complementary elements which are expected to make this method more effective in analyzing and providing valuable inputs for the progress of a company. The basic method used in this research is using operational variables. Drawing conclusions in a causal way where by incorporating elements of Aspiration and results taken from the SOAR methodology to be combined with the SWOT design, it is hoped that it can become a method that can provide better results.
\end{abstract}

Keywords: SWOT, SOAR, Analytical, Business, Method, Planning, Strategic Planning,

\section{INTRODUCTION}

Several previous studies have discussed the industry using SWOT and SOAR. Then in this discussion, we will combine SWOT with the Aspirations and Result elements in the analysis taken from the SOAR approach (Strengths, Opportunities, Aspirations, Results). By combining the elements of aspirations and results in SWOT, it is hoped that the strategic plan targets can be better in 
order to achieve the goals of a company.

The 6 previous studies that are used as the basis are:

1. SWOT Analysis of Marketing Communication Strategy at Sri Baduga Water Park, Purwakarta by Rachmat Nurdien Maulana and Ida Ri'aeni. Where to look at

Marketing mix 4P (Place, Price, People and Promotion). Communication planning can be used for corporate and personal imagery, it can also be used for product imagery. If exclusive imagery leads to personal imagery, imagery in products refers to how the audience can become regular consumers of the goods or products offered. On this basis, marketing must be driven by four basic elements, namely: Products, Place, Price and Promotion. Then use SWOT by looking at Strengths in Product, Strengths in Place, Strengths in Price, Weaknesses in Product, Weaknesses in Price, Weaknesses in Promotion., Opportunities in Product,
Opportunities in Place, Opportunities in Price, Opportunities in Promotion, Treats in Product, Treats in Place, Treats in Price, Treats in Price.

2. Application of SWOT Analysis to Abdullah's KAMSIA BOBA Beverage Business Marketing Strategy in the Midst of the COVID-19 Pandemic in Bangkalan Regency by Fahmi Fadlillah Syaiful and Elihami Elihami. Where to evaluate using scatter diagram analysis / distribution diagram. The implementation of the strategy in the company uses the Growth Oriented Strategy. By using the application of GOS, the company can maximize its strengths to seize the various opportunities that exist so that the company can balance other competitors who issue similar products. Then use a SWOT analysis consisting of Strengths, Weaknesses, Opportunities and Threats.

3. SWOT Analysis in Determining Marketing Strategy by Anissa Mayang Indri Astuti and Shinta Ratnawati. Where Pos Indonesia is a State- 
Owned Enterprise (BUMN) which is engaged in services (postal services). Competitors include JNE, JnT, TIKI and SAP. SWOT analysis is the identification of various factors systematically to formulate company strategies, this analysis is based on reasoning that can maximize strengths and opportunities, but at the same time minimize weaknesses and threats. Where primary data is data collected by someone directly from the object under study and for the benefit of the study concerned which can be in the form of interviews and observations while secondary data is data obtained and collected from previous studies published by various other agencies. then the SWOT analysis is carried out through the IFE (Internal Factor Evaluation) matrix which will describe the biggest strengths and weaknesses of the company and the EFE (External Factor Evaluation) matrix which will describe the opportunity and threat factors owned by the company and the IE (Internal
External) matrix. ) which shows where the company's current position is.

4. SOAR Analysis on Marketing Strategy in the Finance Services Industry by Adelia Alfama Zamista and Hanafi. Where the characteristics of services in this case are divided into four, namely intangible, inseparable, heterogeneity, and quickly lost and fluctuating demand. Soar explained that it is an acronym for strength, opportunity, aspiration, and result. SOAR is a new strategic planning framework developed by Stavros, Cooperider and Kelley in 2009. SOAR is more about identifying and broadening strengths and opportunities. SOAR analysis begins using analysis in the external and internal environment and industry to find out what opportunities are available.

5. Designing Marketing Strategy for Cilembu Cihuy Chips Sweet Potato Chips Using SOAR Strategic by Rizky Fitria Hartuti and Dini Rochdiani. 
Explaining strategic planning that focuses on the condition of the company and human development strategy that originates from all members of the company or organization where the company is planning. Where SOAR is important to do in the Home Industry of Cilembu Cihuy Chips Sweet Potato Chips because it is considered capable of seeing the future strategy of IRT Cilembu Cihuy Chips Sweet Potato Chips in realizing their hopes of becoming a superior product.

SOAR analysis looks at the formulation and implementation of positive strategies by identifying strengths, creating creativity and existing opportunities, raising the aspirations or aspirations of the company and employees, and determining what will happen that is measurable and meaningful both in business development. and analyze the strengths in the company and what opportunities can be exploited. The next step is the imagination stage to design the future that is needed based on the aspirations of all employees. The next stage is the invention (innovate) where the company designs short-term goals, tactical and functional plans, systems, programs, and structures that are integrated in the business. achieve company goals in a synchronized future.

6. Analysis of SOAR Strategy PT. XYZ In Increasing Sales Of Chemical Raw Materials For The Textile, Wood, Clothing And Deterjan Industries by Calvin Chiu. Explained that there are 3 (three) types of chemical raw materials that the company sells, namely sodium sulfate, sodium carbonate, and hydrogen peroxide.

Then describes SOAR Analysis (Strengths, Opportunities, Aspirations, and Results) as an innovative and strengths-based approach to creating strategic thinking and planning that involves all individuals who have an interest in the strategic thinking process. The 
emphasis of the SOAR method is on using the strengths and opportunities of the company. Strengths PT. XYZ is Procurement which utilizes its network, Logistics where service is fast and efficient, Warehousing which always ensures there is stock ready for sale, Sales \& Marketing where qualified salespeople, Finance which is not bound by financial institutions. Opportunities consist of lower interest rates, increased demand for clothing is also an opportunity for the chemical raw material supplier industry indirectly, increased demand for the textile industry has resulted in increased demand for chemical raw materials. Technology provides opportunities in the form of increasing effectiveness and efficiency for the supply industry as well as other industries. The availability of many suppliers makes the bargaining power of suppliers low, homogeneous chemical raw materials make it no substitute for products/services. Aspiration is to increase sales as a supplier of chemical raw materials to the textile and detergent industry in Indonesia, to become a market challenger as a supplier of chemical raw materials where currently its position is still as a market follower, having a solid and compact team with quality. The results are an increase in sales to the textile and chemical industry in Indonesia, an increase in market share in Indonesia as a supplier of chemical raw materials, low employee turnover.

The function of the SWOT analysis is to analyze the strengths, weaknesses and competitive advantages of the company/business which is carried out through an analysis of the company's internal conditions, as well as an analysis of the opportunities and threats faced by the company which is carried out through an analysis of the company's external conditions. In this study, we add elements Aspirations and Results in the analysis taken from the SOAR 
approach (Strengths, opportunities, aspirations,

results). By combining the elements of aspirations and results, it is hoped that the strategic plan targets can be better in order to achieve the goals of a company engaged in the music industry.

\section{MATERIALS AND METHODS /} METHODOLOGY

\section{A. SWOT}

SWOT analysis (strength, weakness, opportunity, treads) is a method used to develop a strategy within the company by looking at the company's environmental conditions, both internal and external. SWOT analysis is used to determine the company's strengths and weaknesses in dealing with existing opportunities and threats. SWOT is Strengths, Weaknesses, Opportunities and Threats. SWOT analysis is used in the company's strategic analysis. Where the SWOT analysis provides information about the company's internal situation and external environment, the company can have an overview of the strategic decisions that will be used. SWOT analysis can be used as a test of the company's internal strengths and weaknesses, and the opportunities and threats of its external environment. Johnson, Scholes \& Sexty (1989) state that SWOT is a general tool designed and used for the initial step in the decision-making process and as strategic planning for various applications. Robinson (2007) states that the SWOT framework can provide an organized basis so that it becomes a material for discussion obtained from various information in an in-depth way which can improve the quality and decisions of the company. generate policies.

However, the SWOT analysis also has limitations and weaknesses. This is because SWOT analysis is a very broad conceptual approach. According to Pearce and Robinson (2007), the shortcomings of SWOT analysis are: 
1. SWOT analysis places too much emphasis on internal strengths and underestimates external threats. Strategy designers must continue to be aware of strategies that have been determined based on the company's internal strengths. This is because the impact of the external environment also has a very large power in influencing the condition of the company.

2. SWOT analysis is static and risks allowing conditions to change. A SWOT analysis is a fleeting view of a changing or moving situation. This condition gives rise to the understanding that the analysis used as the basis for strategic planning must always be alert to the slightest changes in the internal or external environment, so an anticipatory action can be taken so as not to lose the opportunity.

3. A SWOT analysis can emphasize a strength or a strategic element.

4. An uncertain strength becomes a competitive advantage.
B. SOAR

SOAR is a new framework in strategic planning. According to Stavros and Hinrichs SOAR is a strategic planning framework with an approach that focuses more on strengths and seeks to understand the whole system by including the voices of relevant stakeholders. This, according to Stavros et al, (2009) makes the organization currently build the future by means of collaboration, mutual understanding and commitment to action.

SOAR is an acronym for strength, opportunity, aspiration, and result. SOAR is a new framework for strategic planning that has been developed by Stavros, Cooperrider and Kelley since 2009. The SOAR integrates appreciate inquiry (AI) by redesigning strategic planning in SWOT. What makes the difference between SOAR and SWOT is the involvement of stakeholders to identify and analyze strengths and opportunities, thereby creating 
aspirations, goals, strategies, and commitments to achieve results.

The SOAR analysis model assumes that a deficiency factor and also a threat can cause negative feelings towards organizational members, so that it can reduce their motivation to do better. In the SOAR framework, it involves many stakeholders, which is based on the integrity of its members. The issue of integrity will be very important because stakeholders can understand the assumptions that are a driving force for organizational leaders. The identification of the SOAR are:

\section{Strength}

In language it is power. Where in that strength, we can measure the strength that exists against each of us. We must be able to identify the strengths that are within us, which will then be used as an initial capital to proceed to the next stage. This power is a very big asset in us. So it needs to be maximized in recording the assets that we have.

\section{Opportunity}

It is the opportunity of what is possible to be applied. The word opportunity means a momentum to be able to take advantage of an opportunity that is in front of us.

\section{Aspirations}

Aspiration is a step how the future will be achieved. So aspiration is a form of picture of what you want to hope for in the future.

\section{Result}

Result is a result. Results in the form of performance or actions taken and can also produce results. The results have the form, evidence and so on. Then furthermore, from these results can be measured and can also prove about each of us.

\section{SWOTAR}

SWOTAR Is the development of SWOT with the addition of existing elements in SOAR analysis so as to produce Strengths,Weaknesses, Opportunities, Threats, Aspirations, Results. With the method of combining the elements 
that exist in SWOT and SOAR, it is expected to produce a new method of analysis that is better and more competitive for companies engaged in the music industry.

Strength (S), the things that are the biggest strengths and assets owned are disclosed, both tangible assets and intangible assets. The purpose of this disclosure is to give appreciation to all the positive things that are owned, which will always be owned by both individuals and organizations. This strength will continue to be developed for the betterment of organizations and individuals in the future.

Weaknesses (W), These are things the company does not have, or does not do well.

Opportunities (O) means an analysis of the external environment in order to identify the best opportunities that the organization has and can take advantage of.

Threats (T), the opportunity of one company may be a threat to another company. Regulatory changes, substitute technologies, and other competitive forces can pose serious threats.

aspirations (A), members of the organization share their aspirations and design the future conditions they dream of, which can lead to selfconfidence and pride in themselves, their work, departments, and the organization as a whole.

Results (R) means determining the size of the results to be achieved (measurable results) in strategic planning, in order to determine the extent to which the achievement of mutually agreed goals. In order for members of the organization to feel motivated in their efforts to achieve the goals that have been set, it is necessary to design an attractive recognition and reward system.

\section{DECISION MAKING STEPS}

Decision making in solving problems based on alternative analytical models in an organization, decision makers must previously understand the steps in decision making. 
These steps begin with the identification and formulation of the problem, after the identification of the problem followed by the identification of the problem parameters, followed by finding the best alternative that will carry out the decisions that have been taken. In implementing the decision, an evaluation will be carried out to find out whether the results are in accordance with what is expected.

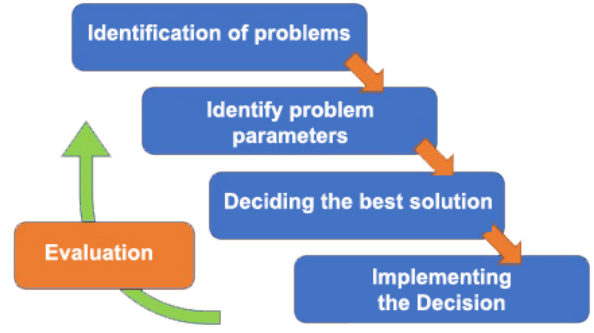

Figure 2.1 Steps to make decisions

Defining the problem by formulating the problem to avoid doubts or different interpretations, followed by abstracting which is related to the reality that occurs in the company. From the abstraction, the model will be used and it is hoped that the results of the analysis can determine the optimal solution. In the end, based on the determination of the optimal solution and management considerations.

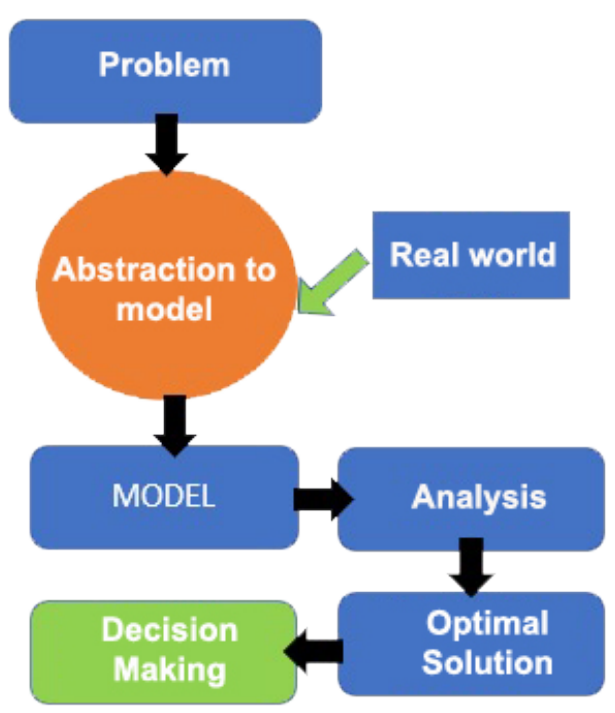

Figure 2.2 Problem formulation process

E. ABSTRACTION STAGE

Abstraction to Model stage is the stage where as a determinant in the selection of the model based on real or real data. This stage is a grouping of the core problems that come from the results of the formulation of a problem.

In abstracting to a model, it is necessary to review the real events that occur in the corporate environment by using several variables as measurement materials 
in later modeling. With these variables, a model can be developed to solve the problem. The model becomes a certain element as data related to the problem to be analyzed.

F. MODEL STAGE

The method used is a combination of SWOT and SOAR concepts. Where the SOAR concept (Strengths, Opportunities, Aspirations, Results) which is an alternative to the SWOT concept which has been widely used as an approach in analyzing companies in designing a strategic plan.

SOAR is an approach popularized by David Cooperrider, in his book Introduction to Appreciative Inquiry (1995). David Cooperrider has previously written in his doctoral dissertation Appreciative Inquiry: Toward a Methodology for Understanding and Enhancing Organizational Innovation, at Case Western Reserve University, Ohio. So you could say, David Cooperrider was the pioneer and the one who popularized this approach.

The SOAR model enhances the wellknown SWOT analysis in analyzing a company both externally and internally, in terms of the organization's internal weaknesses and external threats it faces into the aspiration factors that the company has. and a measurable result to be achieved. This analysis model assumes that deficiency and threat factors can lead to negative perceptions or feelings for members of the organization, this can lead to a decrease in their motivation to do their best.

\section{G. MARKETING MIX 4P}

Place is one of the important things in marketing, and is one of the elements in the $4 \mathrm{P}$ Marketing mix which is not only defined as the place where the business is run, but more generally where the "place" is all product distribution activities in the form of goods or services from producer to consumer (distribution). 
Likewise, the price of a product or service is very important in the marketing mix. This is because in carrying out a strategy, one of them is to make a marketing plan by adjusting the price of a product or service. It is also a very important component because it affects the profitability and business viability of an organization.

People here are mixing the target market with people who are directly involved by paying attention to the number of people involved to market the products or services that we offer. One of the most important is employees at the company, because employees are people who know the advantages of the product or service that the company has.

Promotion is a very important component of the marketing mix because it can increase the brand of a product or service better known in sales. Promotion consists of various elements including: Sales organization. Public Relations,
Advertising, and Sales promotion. Where these elements will involve paid communication methods, both electronic and print.

\section{H. ANALYSIS STAGE}

The analysis stage is the stage that is expected to collect and obtain useful data as a basis for making decisions for solving a problem. In the SOAR Framework, stakeholders are involved as often as possible, which is based on the integrity of its members. The issue of integrity becomes very important because stakeholders must be aware of the assumptions that are the driving force for organizational leaders.

1. Strength (S) Various things that are the strengths and assets of the largest organization owned, both assets owned that have a form or assets that do not have a form. The purpose of recognition for this achievement is to provide recognition of appreciation for all the positive things that are owned, of course positive things will always be owned by both individuals 
and organizations. This strength will continue to be developed for the betterment of organizations and individuals in the future.

2. Opportunities (O) So an analysis of the external environment is carried out to identify the best possibilities that are owned and can be utilized by the organization The external environment is an area full of various possibilities and opportunities. One of the conditions for the success of a company is its ability to maximize the opportunities it has. This indicates that there is a positive perspective in paying attention to the external environment that allows it to change very quickly.

3. Aspirations (A) Every member of the organization from sharing aspirations tries to design and expect future conditions, which will lead to self-confidence and pride both for themselves, for work, for departments or fields, as well as for the organization as a whole. Sharing these aspirations is very useful in creating a mutually agreed vision, mission and values, which will guide the organization's journey towards the future.

4. Results (R) is to determine a measure of the results to be achieved (measurable results) in making strategic planning, in order to determine the extent to which the goals have been agreed upon. In order for every member of the organization to feel motivated in their efforts to achieve the goals that have been set, it is very important to design an attractive recognition and reward system..

The analysis stage in using the SOAR method:

a. Initiate is stages of the organization to determine a decision using the SOAR framework

b. Inquiry is making use of all positive questions is useful for studying and observing the core values, vision, strengths, and potential opportunities of each member of the organization concerned. 
c. Imagination is designing by looking at the expected future. In this phase, values are needed, vision and mission are created in the long term and strategic alternatives.

d. Innovation Is the joint design of short-term goals, tactical and functional plans, programs, systems and structures that are integrated to achieve the expected future goals.

e. Inspire to Implement is: Inspiration to do or implement.

\section{OPTIMAL COMPLETION STAGE}

This stage is the decisive stage in solving problems from the results of the analysis of the methods that have been used, in this case the SOAR method. The results of the analysis using the SOAR method function to identify the situation and position faced by the company in business competition according to the company's internal and external strategic factors faced by the company. SOAR analysis according to Stavros, Cooperrider, and Kelley
(2003) is to describe 2 conditions, namely:

1. Strategic Planning Focus: Doing focused planning on the results of the analysis in the table that shows the strengths and opportunities possessed by the organization or Strengths and Opportunities. Based on the conditions of the company / organization can explain all possibilities.

2. Human Development Strategy: Carry out all the planning that focuses on the results of the analysis of the results of the Aspiration and Results tables. Based on sources from all stakeholders (personal) elements of the company / organization.

\section{J. DECISION MAKING STAGE}

This process is the final process, namely decision making based on real data processing with the selected method approach. This stage will produce a strategic plan that becomes the basis for long-term planning. This decision must be in accordance with the initial objectives of the company 
that are adapted to the environment or circumstances and the availability of company resources.

\section{RESEARCH METHODS}

The basic method used in this research is using operational variables, namely everything in any form determined by the researcher to be studied so that information is obtained about it, then conclusions are drawn (Prof. DR. Sugiono. 2013). Comparison of SWOT and SOAR if we look at there are several things that we can see related to the goals and fields. Where if we look at the objectives, the SWOT analysis is used to find the strengths and opportunities of the company. While SOAR analysis analyzes strengths and opportunities so as to create aspirations, goals, strategies, commitments to obtain results in determining sales strategies. Then if we look at the field, SWOT analysis is used as a company strategy in winning business competition, while SOAR analysis is more on Marketing
Strategy in the Industry. From the results obtained in previous studies, it can be seen that in the SWOT Analysis of Marketing Communication Strategies at Sri Baduga Water Park, Purwakarta as follows:

a. Where S (Strength) is performing performances and also the scenery, the shows that are displayed are very interesting for the visitors, the show is a fountain show that can dance and also the scenery around the fountain garden is very beautiful and beautiful so visitors can linger there. Another strength is a strategic location and the presence of a prayer room. Then Strength on Price, namely the ticket price and the cost of public toilets is not collected, the ticket price is free

b. Where W (Weaknesses) are public toilets and parking spaces are not wide enough to accommodate vehicles from tourists, then the culinary in the water park is not diverse.

c. Where O (Opportunities) i.e. there are spectator stands and prayer room facilities, 
d. Where $\mathrm{T}$ (Treats) is the absence of threats from internal or external parties.

Then in the application of SWOT analysis to the marketing strategy of Abdullah's Kamsia Boba Beverage Business in the Middle of the Covid-19 Pandemic in the Regency, the result is to show where the company's performance can be determined by a combination of internal and external factors. Based on the results of the SWOT analysis, it is obtained that in an IFAS matrix it can show a strength and weakness factor which has a total score of 3.47. So it indicates the effort of kamsia boba is in a very strong internal position.

The coupling of the ST scheme shows that companies must utilize energy before going through the existing vulnerabilities. WO strategy, riding the opportunities that exist to minimize damage to the company. As well as the WT scheme which requires a response to the determination of use using a SWOT study that is in front of the kamsia boba business, that the use of the company's front scheme is tucked into a Growth Oriented Strategy. This is because, in front of the Cartesian sketch of the SWOT study, it is shown that the highest seed quantity ethos is centered on the front of the prime quadrant where the quadrant tucked is advantageous. The effort of kamsia boba saves a lot of opportunity and energy so that it can get on its feet and ride the opportunities that exist while minimizing damage along with various vulnerabilities.

In its implementation, the trade design that has been implemented is the addition of the marketing nature of maximizing online advertisements that are excessively loved by the public, especially young pitchers and rubber bands. Marketing is carried out in various social facilities, namely WhatsApp, Instagram, Twitter, and Facebook. Orders can be made continuously at all social facilities, and free transportation 
advertisements for every purchase of at least 3 products. This shows that the services performed are correct and useful to ensure the continuity of their business and turnover. Then in the SWOT Analysis in Determining the Marketing Strategy of the Case Study at the Magelang City Post Office, the result is to add the position of the Magelang City Post Office 56100 near quadrant I with a SWOT discussion section. The position near Quadrant I describes that the Magelang City Post Office saves opportunities and line styles so that they can ride the existing opportunities. This condition bears the services of an aggressive development (growth oriented strategy). So as not to drown the opportunity for the Magelang City Post Office to expand the market ration for the goodness of postal services that can be offered.

a. SWOT Matrix Analysis for WO Strategy

From the weaknesses and possibilities of the Magelang City Post Office, a strategy can be drawn up to minimize the errors that occur so that the company can ride the possibilities and establish a trading strategy and practice advertising and brand image for most of Magelang City, step on innovate and support the e-commerce market such as shopee, Bukalapak. , and others as well as the increase in soft skills of workers to improve service quality.

b. SWOT Matrix Analysis for ST Strategy

Judging from the strengths and threats, the Magelang City Post Office allocates its strength to overcome weaknesses that can materialize at any time, namely by providing business conveniences and achieved translations to customers' sap percha, establishing competitive translations, intensifying business value added by holding associations that serve customers and brothers. the role and give up the part facilities in carrying out transactions at the Magelang City Post Office. 
c. SWOT Matrix Analysis for WT Strategi Strategy

In the shortcomings and threats that are in the Magelang City Post Office, internal shortcomings can be minimized in order to avoid external threats, namely by using social media for innovative and interesting promotional materials, strengthening technology benefits in supporting services, developing worker creativity and providing timely practice. delivery/transportation of goods.

Then the SOAR Analysis on Marketing Strategy in the Finance Services Industry SOAR Analysis on Marketing Strategies in the Finance Services Industry the results are:

\section{a. Strength}

Based on interviews with branch heads and data that support the results of interviews with PT IMFI employees, it was found that PT IMFI has various positive things (strengths) such as:
1. Regular approach to sales, supervisors (spv), and dealer branch heads.

2. Quick service, can provide satisfaction to dealers and consumers such as quick survey results, surveys outside of working hours.

b. Opportunities

Judging from the internal and external conditions of PT IMFI, the opportunities that PT IMFI has in running the company are:

1) The fact that transportation has become a major need for the community in carrying out activities and opportunities for increasing Indonesia's economic growth

2) Technological advances that have led to the continued emergence of vehicles with the latest innovations make people compelled to buy the latest types of vehicles so that there are many potential RO consumers at PT IMFI.

c. Aspiration 
Aspiration is something that PT IMFI wants to achieve. In this study the goals of PT IMFI are:

1) Increase the number of users of PT IMFI's motor vehicle and heavy equipment financing services

2) Have a solid and quality team

d.Result (Result)

Based on the research results, which are indicators of the company's level of success are as follows:

1) Increasing number of consumers

2) Increase in the number of purchases of motorized vehicles through PT IMFI

3) Low employee turnover

Then in the Marketing Strategy Design of Cilembu Cihuy Chips Sweet Potato Chips Using Soar Strategic the result is Based on the results of the exposure on the SOAR diagram, there are two conditions on the Cilembu Cihuy Chips Sweet Potato Chips. (1) Strategic planning focus where based on the strengths and opportunities that have been analyzed, it can be concluded that Cilembu Cihuy Chips Sweet Potato Chips currently can take advantage of existing opportunities by maintaining the company's strengths. (2) Human development strategy that Cilembu Cihuy Chips Sweet Potato Chips can implement the aspirations expressed by all employees.

From the results of studies that have been carried out regarding several marketing strategies created from SOAR diagrams and matrices, it is formulated what alternative strategies can be used and applied by Cilembu Cihuy Chips Sweet Potato Chips for business continuity, including:

a. The strategy of providing discounted prices on flavor variants that are not the best sellers specifically for gift shops.

b. New limited edition greentea and chili salt special strategy for Shopee.

c. The strategy of updating the packaging design, logo and adding a zip lock. 
d. Strategy for launching cystic and eggroll products with free shipping discounts at the Shopee online store.

e. Promotional strategy of buy 1 get 1 on products that are nearing expiration.

The marketing strategy design that has been created is submitted to all Cilembu Cihuy Chips Sweet Potato Chips employees to be understood more deeply and studied with the aim that all Cilembu Cihuy Chips Sweet Potato Chips employees understand the marketing strategy that has been designed so that it will create measurable results both in the short and long term long on Cilembu Cihuy Chips Sweet Potato Chips.

Then in Soar Strategy Analysis Pt. Xyz In Increasing Sales of Chemical Raw Materials for the Textile, Wood, Clothing and Detergent Industries the results are:

a.Strengths PT. XYZ is as follows (from the interview with the director of PT. XYZ):
1.Procurement. The advantage over the cost advantage by utilizing the network owned by PT. XYZ as a trader.

2.Logistics. The company is able to provide fast and efficient service with its facilities.

3. Warehousing. The warehousing facilities that are owned allow the company to always ensure that there is stock ready for sale and quality control.

b. Opportunities created for PT. XYZ is as follows (from the interview with the director of PT. XYZ):

1. Lower interest rates and stable inflation are expected to increase consumer purchasing power (source: http://www.bi.go.id, accessed on 3 May 2018)

2. Technology provides opportunities in the form of increasing effectiveness and efficiency for the supply industry as well as other industries.

3. The availability of many suppliers makes the bargaining power of 
suppliers low, making it possible to always look for chemical raw materials at the most competitive prices.

4. The homogeneous nature of the chemical raw material commodity makes it no substitute product/service to date.

c. Aspiration that PT. XYZ is as follows (from the interview with the director of PT. XYZ):

1. Increase sales as a supplier of chemical raw materials to the textile and detergent industry in Indonesia.

2.PT. XYZ is a market challenger as a supplier of chemical raw materials, where currently its position is still a market follower.

3. Have a solid, compact and quality team.

d. The results which are indicators of the level of success of a company are as follows (from the interview with the director of PT. XYZ):

1. Increased sales to the textile and chemical industry in Indonesia.
2. Increasing $\%$ of market share in Indonesia as a supplier of chemical raw materials.

3. Low employee turnover.

\section{RESULTS AND DISCUSSION}

The results of the merger appear to be a new, complementary analysis that produces a more complete output that the company can use to carry out its business strategy.

\section{External Factor}

These external factors affect the formation of opportunities, threats, aspirations and results $(\mathrm{O}, \mathrm{T}, \mathrm{A}, \mathrm{R})$. Where this factor is related to the conditions that occur outside the company that affect the company's decision making. These factors include the industrial environment and the macro business environment, economics, legal politics, technology, population, and socio-culture.

2.Internal factors

These internal factors affect the formation of strengths and 
weaknesses ( $\mathrm{S}$ and $\mathrm{W}$ ). Where this factor is related to the conditions that occur in the company, which also influences the formation of company decision making. These internal factors include all kinds of functional management: marketing, finance, operations, human resources, research and development, management information systems and corporate culture.

\section{SWOTER Matrix}

A tool designed to compile a company's strategic factors is called the SWOTER matrix. This matrix can clearly describe how the external opportunities and threats faced by the company can be adjusted to its strengths and weaknesses. This matrix can generate 8 sets of possible strategic alternatives.

\begin{tabular}{|c|c|c|}
\hline NAL & $\begin{array}{l}\text { STRENGHT } \\
\text { (S) } \\
\text { Determine } \\
5-10 \text { power } \\
\text { factors } \\
\text { internal } \\
\end{array}$ & $\begin{array}{l}\text { WEAKNESSE } \\
\text { S (W) } \\
\text { Determine 5-10 } \\
\text { factors of } \\
\text { weakness } \\
\text { Internal } \\
\end{array}$ \\
\hline $\begin{array}{l}\text { OPPORTUNITIE } \\
\text { S (O) } \\
\text { Define 5-10 } \\
\text { Chance factor } \\
\text { external }\end{array}$ & $\begin{array}{l}\text { STRATEGI } \\
\text { SO } \\
\text { Create a } \\
\text { strategy } \\
\text { Who uses } \\
\end{array}$ & $\begin{array}{l}\text { STRATEGI } \\
\text { WO } \\
\text { Create } \\
\text { strategies that } \\
\text { minimize }\end{array}$ \\
\hline
\end{tabular}

\begin{tabular}{|c|c|c|}
\hline & $\begin{array}{l}\text { and the } \\
\text { power to } \\
\text { take } \\
\text { advantage of } \\
\text { opportunitie } \\
\text { s }\end{array}$ & $\begin{array}{l}\text { weaknesses for } \\
\text { kelemahan } \\
\text { take advantage } \\
\text { of opportunities }\end{array}$ \\
\hline $\begin{array}{l}\text { THREATS (T) } \\
\text { Define 5-10 } \\
\text { Threat factor } \\
\text { external }\end{array}$ & $\begin{array}{l}\text { STRATEGI } \\
\text { ST } \\
\text { Create a } \\
\text { strategy } \\
\text { Who uses } \\
\text { power to } \\
\text { Overcome } \\
\text { threats }\end{array}$ & $\begin{array}{l}\text { STRATEGI } \\
\text { WT } \\
\text { Create } \\
\text { strategies that } \\
\text { minimize } \\
\text { weaknesses and } \\
\text { avoid } \\
\text { threat }\end{array}$ \\
\hline $\begin{array}{l}\text { ASPIRATION (A) } \\
\text { Define 5-10 } \\
\text { Aspiration factor } \\
\text { external }\end{array}$ & $\begin{array}{l}\text { STRATEGI } \\
\text { SA } \\
\text { Create a } \\
\text { strategy } \\
\text { Who uses } \\
\text { and the } \\
\text { power to } \\
\text { harness } \\
\text { aspirations }\end{array}$ & $\begin{array}{l}\text { STRATEGI } \\
\text { WA } \\
\text { Create } \\
\text { strategies that } \\
\text { minimize } \\
\text { weaknesses for } \\
\text { kelemahan } \\
\text { take advantage } \\
\text { of aspirations }\end{array}$ \\
\hline $\begin{array}{l}\text { RESULT (R) } \\
\text { Define 5-10 } \\
\text { Factor result } \\
\text { external }\end{array}$ & $\begin{array}{l}\text { STRATEGI } \\
\text { SR } \\
\text { Create a } \\
\text { strategy } \\
\quad \text { Who uses } \\
\text { power to } \\
\text { take } \\
\text { advantage of } \\
\text { the result }\end{array}$ & $\begin{array}{l}\text { STRATEGI } \\
\text { WR } \\
\text { Create } \\
\text { strategies that } \\
\text { minimize } \\
\text { weaknesses for } \\
\text { kelemahan } \\
\text { take advantage } \\
\text { of the results }\end{array}$ \\
\hline
\end{tabular}

\section{SO Strategy (Strength}

\section{Opportunities)}

This strategy is made based on the company's mindset, namely by utilizing all strengths to seize and take advantage of opportunities as much as possible

2. ST Strategy (Strenghts -Threats) 
Is a strategy in using the strengths of the company to overcome threats.

3.WO Strategy (Weaknesses Opportunities)

This strategy is implemented based on the utilization of existing opportunities by minimizing existing weaknesses.

\section{WT Strategy (Weaknesses-Threats)}

This strategy is based on activities that are defensive in nature and seeks to minimize existing weaknesses and avoid threats.

\section{SA STRATEGY (Strenghts -} Aspiration)

This strategy is made based on the company's way of thinking, namely by utilizing all strengths to seize and take advantage of the greatest aspirations

\section{SR STRATEGY (Strenghts - Result)}

This strategy is made based on the company's mindset, namely by utilizing all results to seize and take advantage of opportunities as much as possible
7.WA STRATEGY (Weaknesses Aspiration)

This strategy is implemented based on the utilization of existing aspirations by minimizing existing weaknesses.

\section{WR STRATEGY (Weaknesses -} Result)

This strategy is implemented based on the utilization of existing results by minimizing existing weaknesses.

\section{CONCLUSION}

By combining the elements of Aspirations and Results in SWOT, it is hoped that the strategic plan targets can be better in order to achieve the goals of a company.

SWOT analysis is an analysis of the factors Strengths, Weaknesses, Opportunities, and Threats. Meanwhile, SOAR analysis is an analysis of Strengths, Opportunities, Aspirations and Results. The results of combining the two analyzes appear to be a new, complementary analysis 
that produces a more complete output that the company can use to carry out its business strategy. There are 8 sets of possible strategic alternatives that can be generated from combining the two analyzes, namely: SO Strategy (Strength - Opportunities), ST Strategy (Strengths -Threats), WO Strategy (Weaknesses Opportunities), WT Strategy (Weaknesses-Threats), SA Strategy (Strengths - Aspiration), SR Strategy (Strengths - Result), WA Strategy (Weaknesses - Aspiration), and WR Strategy (Weaknesses - Result).

There are several stages of the problem formulation process with a method approach to take optimal solution decisions, namely: Abstraction, Model, Analysis, Optimal Solution, and Decision Making. The combination of SWOT and SOAR concepts can be used at the Model stage.

In the analysis that has been carried out, it appears that there are differences between the SWOT method and the SOAR method, in terms of fields, objectives and methods used. However, each of these methods can complement each other.

\section{REFERENCES}

[1] Rangkuti, Freddy.2017. Teknik Membedah Kasus Bisnis Analisis SWOT. PT. Gramedia Pustaka Utama, Jakarta.

[2] Wiwid Syahdiyah, Sugiarti. (2017). Analisis Strategi Pemasaran Produk Usaha Mikro Kecil Menengah Melalui Metode Analisis SOAR pada UMKM Kue Cubit Laina Di Medan. Medan, Repository.usu.ac.id

[3] Stavros, J., \& Hinrichs, G., 2009. Thin book of SOAR Building strengh-based strategy, Bend,OR Thin Book Publisher.

[4] Ikhsan, S dan Aid Arthan. (2011). Analisis SWOT untuk Merumuskan Strategi Pengembangan Komoditas Karet di Kabupaten Pulau Pisang, Kalimantan Tengah. Jurnal Agribisnis Pedesaan.

[5] Johnson, G, Scholes, K., \& Sexty,R.M., ～(1989), Exploring 
Strategic Management, Scarborough, Ontario: Prentice Hall.

[6] Pearce, John A. Robinson JR, Richard B, alih bahasa Yanivi Bachtiar dan Christines. 2007. Manajemen Strategik: Formulasi, Implementasi dan Pengendalian. Buku Satu.Penerbit Salemba Empat. Jakarta.

[7] Jakes T.D. 2017. SOAR Build Your Vision from the Ground Up by TDJ Enterprises, LLP.

[8] Maulana Rachmat Nurdien dan Ri'aeni Ida, 2020. Analisis SWOT Strategi Komunikasi Pemasaran Pada Taman Air Sri Baduga, Purwakarta, Jurnal Ilmu Komunikasi, Volume 1, No. 1.

[9] Syaiful Fahmi Fadlillah dan Elihami Elihami, 2020. Penerapan Analisais SWOT Terhadap Strategi Pemasaran Usaha Minuman KAMSIA BOBA Milik Abdullah di Tengah Pandemi COVID-19 dI Kabupaten Bangkalan, E-ISSN: 2715-2634.

[10] Astuti Anissa Mayang Indri dan Ratnawati Shinta, 2020. Analisis SWOT Dalam Menentukan Strategi
Pemasaran, Jurnal Ilmu Manajemen, Volume 17, Nomor 2, 2020.

[11] Zamista Adelia Alfama dan Hanafi, 2020. Analisis SOAR pada Strategi Pemasaran di Industri Jasa Finance, Jurnal Hasil Penelitian dan Karya Ilmiah dalam Bidang Teknik Industri.

[12] Hartuti Rizky Fitria dan Rochdiani Dini, 2021. Perancangan Strategi Pemasaran IRT Keripik Ubi Cilembvu Cihuy Chips Menggunakan SOAR Strategic, Jurnal Pemikiran Masyarakat Ilmiah Berwawasan Agribisnis.

[13] Chiu Calvin.,2018 Analisis Strategi SOAR PT. XYZ Dalam Menemgkatkan Penjualan Bahan Baku Kimia Untuk Industri Tekstil, Kayu, Pakaian Dan Deterjan, Jurnal Manajemen Bisnis dan Kewirausahaan. 